(1) $(9)$ This work is licenced under the Creative Commons Attribution 4.0 International license for non-commercial purposes.

\title{
[ From Property-Owning Democracy to Generation Rent? Analysing Theresa May's Housing Rhetoric from the Perspective of the Discourse Historical Approach ]
}

\author{
Alice Tihelková, Veronika Quinn Novotná \\ University of West Bohemia, \\ Plzeň, Czech Republic
}

[Abstract] Since the 1920s, British Conservatives pursued the concept of property-owning democracy, with home ownership viewed as a guarantor of social stability and personal autonomy. However, recent increases in housing costs have made the "British Dream" of home-ownership more elusive than ever, with renting becoming a lifelong prospect for large swathes of people. Using the Discourse Historical Approach, a method falling within Critical Discourse Analysis, the article analyzes the 2019 housing speech by Prime Minister Theresa May to ascertain whether the changing situation has been reflected in the Conservatives' housing rhetoric, traditionally driven by a property-owning ethos. Examining May's argumentation and language use, it concludes that May's proclaimed commitment to renewed council house construction represents both a long-overdue acknowledgement of the housing affordability crisis and a pre-election strategy to win Labour voters.

[Keywords] Discourse Historical Approach; DHA; Critical Discourse Analysis; CDA; council housing; Theresa May; property-owning democracy 


\section{[1] Introduction}

The concept of property-owning democracy has long represented a key policy of the British Conservative Party and one of its vote-winning strategies. The importance of home ownership to British people cannot be overstated; while elsewhere in Europe people are happy to rent their homes without feeling socially inferior for doing so (Flint, 2021), being a homeowner in Britain amounts to a symbolic confirmation of an individual's stake in society. Throughout the twentieth century, the Conservative Party skillfully used the home ownership dream to both attract voters and ensure their compliance with the status quo. The myth that a home-owning society was more stable, content and civically-minded was perpetuated in a plethora of speeches by Conservative politicians such as Anthony Eden, Harold Macmillan or Margaret Thatcher, the assumption being that the share of owner-occupied homes in Britain's housing stock would continue to grow steadily (Sandbrook, 2019, p. 230).

Developments at the start of the twenty-first century, however, made a dent in the home-owning hopes of Britons. Rising prices of property and the general cost of living, as well as other social and economic factors (see Tihelková, 2016, p. 194), have resulted in a marked decrease in home ownership, the rate of which currently stands at 65 per cent as compared to 73 per cent in 2000. Increasingly, private renting is becoming a long-term prospect for income groups that would previously have become homeowners. ${ }^{1}$

The present paper aims to inquire whether/how the recent decline in housing affordability is reflected in the political discourse of the Conservatives, the party that has been in power in Britain for the past 12 years. More specifically, it seeks to ascertain whether any major adjustments to the traditional home ownership-oriented rhetoric of the Conservatives have been made vis-à-vis the current housing crisis and what argumentation is used to justify any such adjustments. This inquiry is conducted by means of an analysis of a speech delivered by Theresa May to the Housing 2019 conference in Manchester (Inside Housing, 2019). The speech was selected since it is wholly devoted to the issue of housing and encapsulates the party's housing policy over May's entire premiership. The speech is analyzed from the perspective of the Discourse Historical Approach (DHA), a method falling within the field of Critical Discourse Analysis (CDA). The choice of the DHA was motivated by the need for historical context to assess the content and argumentation strategies present in Theresa May's speech. The analytical procedure used in the paper is informed by the approach applied by Ruth Wodak in her research of political rhetoric. In particular, the model presented in Wodak's analysis of David Cameron's Bloomberg speech on the European Union has been broadly followed (see Wodak, 2016).

\section{[2] Property-owning democracy: historical context}

The well-documented preoccupation of the British with the property market may give a false impression of Britain's long history of private home ownership, yet only 10 per 
cent of British houses before World War One were actually owner-occupied (Hunt, 2004). Both middle- and working-class households lived predominantly in rented properties, either for convenience or due to a lack of means. The end of the war, however, marked a significant shift. Faced with the risk of radical Socialism spreading in the economically volatile post-war era, politicians sought ways to stabilize the society. While Lloyd George's Liberals as well as the Labour Party preferred to deal with the housing situation through the construction of council housing, the Conservatives embraced the idea of boosting private property ownership as a way to secure the consent of the public with the status quo, with property-owning democracy becoming the underlying concept.

Formulated by the Scottish MP Noel Skelton (who also coined the term), the idea of property-owning democracy was based on the argument that while the advance of mass democracy extended political and educational rights to the public, it failed to extend their economic rights, a situation that threatened to radicalize the society. To remedy the disparity, Skelton envisaged a programme of redistributive measures to steer workers away from any radical political alternatives. Although Skelton's programme was not adopted in its entirety, his claim that property ownership gave people a stake in society and should be encouraged by government measures became an integral part of future Conservative policies (Ron, 2008).

Under the Conservative administrations of the 1930s, Britain saw a major boom in the construction of homes for owner-occupation. The Conservatives, seconded by advertisers, sought to market home ownership as a ticket to a life of respectability and civic decency, with emphasis placed on the safety and high quality of life in owner-occupied enclaves. It was in this period when home ownership became the ultimate indicator of social mobility.

In the years following the Second World War, it was the council housing sector that grew in scale and importance under the visionary plans of Labour Minister Aneurin Bevan, who dreamed of the state becoming the dominant provider of homes. The construction of large council estates offering low-density housing of a high standard became one of the pillars of the post-war Welfare State. Parallel to that, however, the vision of property-owning democracy was rekindled by a number of Conservative leaders, most notably Anthony Eden and Harold Macmillan. Addressing the 1946 Conservative Party conference, the former made a distinction between the socialist model "where everyone must rely on the State for his job, his roof, his livelihood" and the Conservative proposition "that the ownership of property is not a crime or a sin, but a reward, a right and a responsibility that must be shared as equitably as possible among all our citizens" (Ball, 1998, p. 104). Although council housing continued to be built under post-war Conservative cabinets, it gradually came to be seen as last-resort housing for those who "could aspire to no better" (Boughton, 2018, p. 58), the assumption being that aspirational workers, whether middle class or skilled working-class, would eventually become homeowners.

The idea of property-owning democracy enjoyed its heyday under the premiership of Margaret Thatcher, who significantly extended private home ownership by selling off council homes to tenants at discount prices, a policy known as Right to Buy, launched in 
1980. Thatcher saw private ownership as the bedrock of a free society. In her view, owner occupation of homes fostered independence, respectability and a sense of civic pride, while council housing was conducive to passive dependence on the state. In her speech to the National Housebuilding Council, Thatcher famously equated home ownership with freedom and full participation in society:

Wherever we can we shall extend the opportunity for personal ownership and the self-respect that goes with it. [...] Three hundred and seventy thousand families have now bought their own homes from councils, new towns and housing associations. [...] Half a million more people will now live and grow up as freeholders with a real stake in the country and with something to pass on to their children. There is no prouder word in our history than "freeholder". (Sandbrook, 2019, p. 236)

Having created a new propertied class of aspirational workers, Right to Buy was a vote-winner, with Thatcher touting it as the largest transfer of assets from the state to the people. It undoubtedly gave swathes of people the opportunity to own assets which provided them with long-term security and which they could pass on to their children. On the other hand, it reduced the housing stock available to councils to house people unable to buy their home or afford private rent. Far from laying the foundations of long-term property-owning democracy, Right to Buy was a give-away to one generation of buyers, leaving future generations empty-handed and increasingly dependent on the highly volatile private rental market.

\section{[3] Discourse-Historical Approach}

Pioneered by the Vienna-based scholars Ruth Wodak and Martin Reisigl and further developed at research institutions in Lancaster, Loughborough, Bern, Örebro and elsewhere, the Discourse-Historical Approach (DHA) forms a subset of the broad field of Critical Discourse Analysis (CDA). The purpose of CDA research, according to Teun van Dijk, is to examine the ways in which social power, dominance, abuse, and inequality are enacted, reproduced, and resisted by written and spoken text in the social and political context (van Dijk, 2003, p. 352). Norman Fairclough, one of CDA's founding fathers, defines the discipline as a multidisciplinary approach to discourse which views language as "a form of social practice" (Fairclough, 1992, p. 4). Going beyond the mere study of the linguistic properties of texts, CDA seeks to reveal the ideologies working through discourse and show how they are related to the broader social order. Far from being detached from the issues uncovered, the critical discourse analyst, as argued by Michael Meyer, takes the side of the underprivileged and seeks to reveal the linguistic means used by the privileged to stabilize or even increase social inequalities (Meyer, 2001, p. 30).

Similar to CDA, the DHA is preoccupied with uncovering ideology embedded in discourse, defined as "(often) one-sided perspective or world view composed of related mental representations, convictions, opinions, attitudes and evaluations, which is shared by members of a specific social group" (Reisigl and Wodak, 2017, p. 88). The ap- 
proach seeks to integrate the knowledge of the historical context of discourses and may also attempt to trace diachronic changes in various discourse types. Like CDA, the DHA does not involve the use of a single, specific method; it applies any methods that help it fulfil its objectives. The DHA regards discourse analysis not only as a method of language analysis but as a multi-dimensional project that integrates methodologies and research practices from the fields of sociolinguistics, pragmatics, semiotics, rhetoric, sociology, history and others. The works of Erving Goffman, Pierre Bourdieu, Ludwig Wittgenstein, Stephen Toulmin, Jürgen Habermas or Reinhart Koselleck are some of the major theoretical points of reference for DHA inquiry (Reisigl, 2018, 48).

The DHA was first applied in a research study of anti-Semitic stereotypes emerging in public discourses of the presidential campaign of Kurt Waldheim in Austria in 1986. Four distinct features of the approach took form during the project: its interdisciplinarity and historical focus, teamwork, triangulation of data and methods, and the ambition to apply the findings in practice (Reisigl, 2017, p. 45). Since then, the topic areas investigated by the DHA have included, among others, overt and covert forms of racism in political discourses in the parliaments of some EU member states, mainly in relation to migration and asylum-seeking, communication within the organizations of the EU, discourses of employment and unemployment in EU committees, and the construction of European identities in the speeches of British, French and German politicians, such as David Cameron's Bloomberg speech on the EU, etc. (see Wodak, 2018).

Unlike Fairclough and other CDA researchers, whose analysis is based on functional linguistics, Ruth Wodak and the analysts working within the DHA framework focus on textual analysis, argumentation theory and rhetoric. Their triangulatory approach is based on the concept of "context", which takes four levels into account:

- the immediate linguistic context

- the intertextual/ interdiscursive relationships between texts/discourses

- the extralinguistic social and institutional context

- the broader socio-political and historical context of the discourse (Reisigl and Wodak, 2018, 93).

From the methodological point of view, the DHA is anchored in a qualitative approach (comprising a wide range of qualitative methods applied as required, including focus groups, ethnographic research, conversational or multimodal analysis, etc.). Contrary to the widespread use of corpus-oriented approaches in CDA, the DHA treats quantitative description of material as background information, placing main emphasis on in-depth analysis of texts. According to the DHA, in-depth text analysis can only be achieved by a consistently applied interdisciplinary approach. ${ }^{2}$

\section{[4] Analysis of Theresa May's speech}




\section{[4.1] Macro-topics}

The speech analyzed below was delivered at the Housing 2019 conference and exhibition in Manchester on 26 June 2019, only weeks before May's resignation as Prime Minister. It was conceived of as a defence of the departing administration's record on housing as well as an outline of future housing policies. These, May argues, should include new regulations to ensure affordable homes of good quality as part of an "ongoing housing revolution" (PM's Speech on Housing, 2019). Within the confines of the revolution, the government should newly prioritize the housing needs of renters instead of solely supporting homeowners.

Listed below is the sequence of macro-topics in Theresa May's speech:

- May's intention to resign as Prime Minister

- Identification of housing as one of the key themes of her ending premiership

- Listing the achievements of her Cabinet in the field of housing

- Implementation of structural changes to the housing sector introduced by the Cabinet

- Acknowledging the role of property ownership

- Introducing the new priority of policymaking on behalf of renters

- Announcing a plan to build more council homes

- Giving greater protection and empowerment to renters

- Ensuring new quality standards for rental homes

- Commitment to safe and affordable homes for everyone

Surprisingly for a Conservative leader, in her speech May calls for more council homes to be built, describing social housing as "a victim of the single-minded drive for home-ownership". She also insists that building large numbers of new homes is only one part of the solution; the other involves the quality of such homes:

A hundred years after the introduction of Britain's first council houses, I want to see not just homes that people have to live in but homes they want to live in, homes they can be proud to live in. And that drive for greater quality, for higher standards, should extend right across the housing industry. For too long we have allowed ourselves to think there must be a trade-off between quality and quantity, that raising one means reducing the other. It is simply not true. I do not accept that, in 2019, we can only have sufficient and affordable housing by compromising on standards, safety, aesthetics, and space.

To put things into context, the post-war Conservative strategy for building council homes was to construct mass manufactured high-density buildings from cheaper material built to lower standards. This housebuilding strategy replaced the low-density cottage-type homes with spacious rooms and gardens favoured by the post-war Labour housing visionary Aneurin Bevan (Hanley, 2012, p. 79). This was partly due to the need to 
build in greater quantity and at a faster rate, but in addition to that, the reduction of the quality of council homes reflected the changing view of their role: instead of being envisioned as solid homes for aspirational manual and clerical workers, they came to be seen as last-resort housing for those too poor to consider buying their own home. May's call for a higher structural and aesthetic standard of the new council homes suggests her recognition of the fact that broader sections of society, not only low-income groups, will prospectively be cut off from home ownership and dependent on rental housing. The assumption that only the poor will rent is no longer valid.

\section{[4.2] Argumentative structure}

The Prime Minister begins her speech by recalling her appearance at the same venue three years earlier, an event blighted by her speaking difficulties due to coughing as well as an interruption by a protester waving a P45 form (a document a person fills out in the UK on the occasion of leaving his/her job). She attempts to put a humorous spin on the memory, reassuring her audience that her staff backstage are waiting with some cough sweets should she need them. In addition, she announces she will be stepping down as Prime Minister in a few weeks' time, making any protest actions urging her to leave somewhat overdue.

With her departure looming, she clearly seeks to deliver a legacy speech; one which will, given that she is speaking at a housing event, highlight her achievements in the housing sphere. Her objective is to present herself as someone who, working closely with her Cabinet and the housing sector, has succeeded in turning Britain's dire housing crisis around, leaving her successor with an upward trend:

Here in Greater Manchester the number of extra homes being created has risen by more than 12 per cent. In Nottingham, by 43 per cent. In Birmingham, by an enormous 80 per cent. The notable exception is London - where housing policy is in the hands of the Mayor, and the number of new homes being created has actually fallen by a staggering 20 per cent.

The inclusion of London as an exception is deliberate, as its Mayor, Sadiq Khan, is a Labour politician; therefore, a contrast is made between the successful Tory councils and the allegedly underachieving Labour ones.

Thereafter, the Prime Minister goes on to pledge a million affordable homes within less than five years, specifying who these homes will primarily be intended for: "young families, for hardworking professionals, for downsizing retirees." Such a selection of beneficiaries reflects the traditional stereotype of the "deserving" section of the population (Tihelková 2015, p. 125), which has been an integral part of Conservative rhetoric for much of the party's existence. Those who are aspirational, hardworking, or who have made their contribution to society before retiring, are deemed eligible for inclusion in the planned housing project. By implication, those not falling into the category (traditionally, the "undeserving" frame has been applied to working-age individuals not in paid 
employment, i.e. dependent on welfare relief) are not among the intended target group. May clearly seeks to present her housing scheme as a project for those who are upwardly mobile or, on the other hand, for those who have completed their successful career paths. The people who are in fact in the greatest need of affordable housing (i.e. socially vulnerable individuals with complex issues, whether related to physical or mental health or low socio-economic status) are not mentioned. Such a concept harks back to the early days of council housing at the turn of the twentieth century, when the newly built rental complexes, such as the Boundary Estate in Poplar or Old Oak in Hammersmith, were primarily intended for (and affordable to) the more prosperous segments of the working class, i.e. skilled workers, or, indeed, white-collar workers (Boughton, 2018, p. 21). ${ }^{3}$

The inclusion of "hardworking professionals" among the group needing affordable housing amounts to an admission that relatively affluent individuals are struggling in the overheated housing market. Here, May makes a stark break with the previous Conservative housing narrative by the admission that home ownership may no longer be a viable prospect for millions of Britons. While dedicating a short part of her speech to her government's continued commitment to property-owning democracy, making references to Noel Skelton and Harold Macmillan (though interestingly not to Margaret Thatcher, the policy's staunchest advocate), she focuses the remainder of her speech on the issue of rental housing. Using the topos of necessity, she stresses the importance of government support for renters amidst the withering away of the chances for home ownership:

We recognise there are people for whom home ownership will never be a realistic aim. That there are others for whom renting is an unavoidable reality at one time or another. And that some people simply choose to rent, especially if it allows them to live in an area they would otherwise struggle to afford. Being able to choose to rent a decent home in the place that suits you best is a vital part of a healthy housing system, one we see in every major developed economy. Across England, more than 18 million people from every walk of life woke up this morning in a rental property. And no government should ignore the needs of so many of its citizens. So yes, I want to see as many people as possible enjoying all the benefits of home ownership. But that should not stop us working to improve renting too - and this government has taken real action to do just that.

Such rhetoric represents a novelty in the Conservative attitude to housing. Margaret Thatcher extolled private home ownership as a sign of a developed, free and well-ordered society. Similarly, David Cameron, May's predecessor, supported the ongoing sell-off of public housing into private hands (Watt, 2012). May, on the other hand, newly sees a functioning rental system as an indicator of an advanced economy. She no longer equates home ownership with liberty, civic virtue and personal independence, appearing well-aware of the reduced prospects of homeownership among those who would be potential buyers in Thatcher's era.

Just as striking as the complete omission of Thatcher in her speech (despite her mention of other Conservative prime ministers) is May's reference to Christopher Addison, the Liberal author of the 1919 Addison Act, which enabled a mass-scale construction 
of council houses after the First World War. By bringing Addison into the debate, May demonstrates her embrace of a housing concept running parallel to that of property-owning democracy: the construction of council housing as one of the pillars of Britain's welfare state. Unlike Thatcher, for whom council housing ran against her values of self-reliance and aspiration, May presents it as a solution to the provision of safe, affordable housing. By doing so, she clearly steps onto the territory of the Labour Party, which has spent years calling from the opposition benches on the Conservatives to invest in public housing. Led by Jeremy Corbyn, Labour promised in its 2017 election manifesto to "launch a new era of council house building" and build "100,000 new genuinely affordable homes” each year (Kentish, 2017), a pledge to which May's proposed policy bears an unmistakable resemblance. Similarly, the removal of the Housing Revenue Account (HRA) borrowing cap, a step May took to enable councils to borrow more money for housebuilding, had been on the Labour agenda since 2014 (Jameson, 2014). It can, therefore, be assumed that an attempt to capture the Labour vote is one of the motives informing May's housing strategy.

Pledging to build council homes that are both affordable and of high-quality, May uses the topos of history in referring to the 2016 tragedy of Grenfell Tower, a fire at a high-rise tower block in the London borough of Kensington, which saw 71 people killed and dozens of others injured. The low-quality flammable cladding on the building, occupied mostly by low-income households (many of them ethnic minority families), was symptomatic of the second-rate position of council housing, which had been transformed from a universal provider to a last-resort sector for the society's neediest. In her speech, May expresses outrage at the neglect of housing standards and sympathy for the victims of Grenfell, promising to build higher quality houses in the future. However, it is somewhat ironic that, in the wake of the 2016 tragedy, she actually refused to meet the survivors of the fire (unlike her rival Jeremy Corbyn), being too apprehensive about facing the anger of those who had suffered decades of inadequate housing. According to Peter Apps of Inside Housing, the moment when she fled to her car without pausing to speak to the gathered community "became an icon of the gap between the political class and the victims in the chaotic days after the disaster" (Apps, 2012). In addition, her response to the emergency situation faced by Grenfell survivors was marked by delay and inaction, with a number of families still housed in hotels or temporary accommodation two years later.

\section{[4.3] Use of language}

Theresa May's speaking style reflects her effort to project an image of a practical, task-oriented politician, with a set of workable policies ${ }^{4}$ at hand:

So we are bringing to an end the practice of so-called "no-fault" evictions, repealing section 21 of the 1988 Housing Act. A consultation on the changes will be published shortly, with a view to introducing legislation later this year. For tenants in England's four million social homes we have scrapped the so-called "pay to stay" policy and confirmed 
that this government will not pursue plans to abolish lifetime tenancies for new council tenants. We have retained supported housing in the welfare system - listening to those who know best about how to protect our most vulnerable citizens.

Her desire to come across as a hands-on problem solver also manifests in her choice of modal verbs, particularly in her decisive preference for deontic (28 instances) over epistemic (12 instances) modality. According to Greenbaum, deontic meanings "refer to some kind of human control over the situation," while epistemic meanings "refer to some kind of judgment of the truth-value of the proposition” (Greenbaum, 1996, 260). May's discourse is largely free of assumptions or hypothesizing; she is not concerned with possibilities but with getting things done:

[1] But that should not stop us working to improve renting too - and this government has taken real action to do just that.

[2] I have always been clear that this green paper must not be simply an intellectual exercise highlighting the nature of the problem. It must be the practical first step in actually fixing it.

[3] So today I can announce that the next stage in the process, our action plan and timetable for implementing wide-ranging reforms of social housing, will be published in September.

As far as the use of pronouns is concerned, we and I dominate in May's speech. We occurs more frequently (45 times) and is used to refer to the following:

- May's Conservative cabinet; she uses the pronoun to refer to its past, present or future attitudes, plans and actions (36 instances):

[4] We recognise there are people for whom home ownership will never be a realistic aim. So we are bringing to an end the practice of so-called "no-fault" evictions.

- British people in general (9 instances):

[5] It is the political world's focus on the grand gesture rather than incremental change that is partly responsible for the crisis we are dealing with today.

Occurring 29 times, the pronoun $I$ is used when May speaks on a more personal note and refers to her individual actions or attitudes:

[6] Because of course, in a few weeks from now $I$ will be stepping down as Prime Minister.

[7] I do not accept that, in 2019, we can only have sufficient and affordable housing by compromising on standards, safety, aesthetics, and space.

In addition, the pronoun they (occurring 14 times) is used to refer to a variety of agents, most often tenants or people seeking affordable housing, who are referred to in a sympathetic tone: 
[8] Across the country, people complained of living in substandard or unsuitable housing - and said they felt ignored and disrespected by their often remote and unaccountable landlords.

[9] I want to see not just homes that people have to live in but homes they want to live in, homes they can be proud to live in.

There is an absence of they in the sense of a political or social opponent. Besides a brief comment on the Labour's inability to build more homes in London and a pledge not to repeat the housing mistakes of her own party, May's speech is relatively devoid of criticism or adversarial discourse. This, among other reasons, may have to do with the fact that she is a departing Prime Minister seeking to end her term on a positive note.

In her choice of vocabulary, the Prime Minister consciously feeds into her public image of a steadfast, reassuring person, a safe pair of hands, working with her team in a gradual but steady manner towards her goals:

[10] It must be the practical first step in actually fixing it.

[11] And everyone in this country can look ahead to a future in which each of us has a safe, affordable place to call home.

[12] Because hand in hand, step by step and piece by piece, the government and the sector have begun to turn around the crisis in British housing.

And while Thatcher often used keywords such as freedom, choice or pride when referring to home ownership, May, on the other hand, works with the concept of fairness when laying out her vision for new rental homes:

[13] It is simply not fair. So we are bringing to an end the practice of so-called "no-fault" evictions, repealing section 21 of the 1988 Housing Act.

[14] We promised $a$ better deal for renters, we have started to deliver $a$ better deal for renters.

[15] As a mandatory regulation, space standards would become universal and unavoidable. That would mean an end to the postcode lottery for buyers and tenants.

It would be tempting to interpret May's appeals to fairness as another example of her appropriation of traditional Labour policies; after all, "Future Fair for All" was the title of Labour's 2010 election manifesto. Nevertheless, references to fairness can also be found in Conservative rhetoric ${ }^{5}$; the concept is certainly not Labour's speciality. As argued by Rogers (2014), however, both parties typically appeal to a sense of fairness when addressing economically struggling voters. ${ }^{6}$ When Thatcher was extolling the virtues of home ownership, she was speaking to the upwardly mobile segments of British society; to individuals whose prospects of improving their material situation by acquiring property were realistic at the time. They were members of either the middle class or the skilled working class on course to embourgeoisement by the acquisition of property through the Right to Buy scheme. By 2019, such a prospect had become more difficult to sustain as ever greater swathes of the population struggled to gain access to housing. In reflection 
of the changed circumstances, May pledges to assuage some of the adverse effects of the housing crisis instead of encouraging unrealistic visions of mass home ownership with its concomitant personal benefits.

Finally, though they are not numerous, some metaphors are used by the Prime Minister to illustrate her points. Negative metaphors are largely used to denote the non-productive policies of the past or the non-existence of instant solutions (16), (17), whereas positive metaphors highlight May's proclaimed competence as a housing policymaker (18):

[16] The lack of universal standards encourages a race to the bottom.

[17] There is no single silver bullet. No button to press or lever to pull that can magically make millions of homes appear overnight.

[18] That is why we are... giving more than half a million households a step up the housing ladder.

To summarize, May's choice of language reflects her ambition to reassure her audience of both her understanding of the plight of renters and her government's competence in policymaking on their behalf. Moreover, her frequent references to concepts such as fairness, affordability and housing regulation suggests that she is making a clear appeal to Labour voters (currently the largest voter group among Britain's renters ${ }^{7}$ ) in addition to addressing her own electoral base.

\section{[5] Rhetoric versus reality}

Despite May's best efforts to deliver her speech on an optimistic note emphasizing her Cabinet's ability to deal with the housing crisis, her actual housing legacy remains mixed. Her expressions of sympathy with Grenfell victims are at odds with the lack of decisive action to rehouse its tenants in the wake of the tragedy. The government's approach to construction safety in other places has also been slow: hundreds of tower blocks remain clad with flammable material that could lead to a repetition of the Grenfell tragedy. In addition, as May was leaving office, the numbers of new social rented homes being built remained at a historic low - only 6,436 in a year, the second-lowest number on record, as compared to 300,000 council homes a year delivered by Harold Macmillan, the post-war Conservative Prime Minister who is celebrated as a role model in May's speech (Gimson, 2013).

On the other hand, even subjects considerably to the left of May's political position tend to agree that in spite of her failure to deliver the number of new homes needed, her major contribution to housing policy was the rescue of the concept of socially rented housing from the oblivion to which it was consigned by David Cameron's cabinet. Her decision to remove the cap on borrowing to build council homes is considered as particularly significant. As argued by housing expert George Apps (2019):

For the six years since the Spending Review in 2010, no public money had been committed for new social rent for the first time since World War II. Theresa May turned this 
around. Her conference speech in 2017 is remembered as a car crash when she was laid low by a cough, but that obscured the fact that she announced grant funding for new, genuine social rented homes for the first time this decade. A year later, she trumped that, dropping the cap on council house borrowing in its entirety in what is undoubtedly the most decisive and significant housing policy move during her three years in charge and may yet herald a renaissance in council housebuilding.

Therefore, in spite of the lack of tangible results regarding the construction of new rental homes, it can safely be argued that in terms of the housing visions of Conservative Prime Ministers of the past 30 years, May's has been the most radical and in touch with Britons' need for affordable housing, potentially providing a strategy blueprint for her political successors.

\section{[6] Conclusion}

Studied against the backdrop of earlier Conservative housing policies overwhelmingly centred on private home ownership, an inquiry made possible by involving historical context as part of the DHA approach, Theresa May's 2019 housing speech reveals a distinct shift of focus involving her commitment to improving the situation of Britain's renters. In her rhetoric, rental housing, especially council housing, traditionally perceived by the Conservatives as the sector catering to the society's less successful members, becomes reframed as a vital component of an advanced economy. The equation of home ownership with a stake in society and personal independence is dropped; instead, high-quality rental homes are presented as a respectable housing choice. May's plans for building affordable rental housing closely resemble the pledges of Jeremy Corbyn's Labour Party, suggesting a possibility of May's purposeful appropriation of Labour policies to win over the votes of metropolitan renters, generally more predisposed to vote Labour (tellingly, the speech was delivered a few months before the general election of 2019). On the other hand, the Conservative U-turn on housing performed by May is just as likely to be motivated by the realistic assessment of the housing trends in the current socio-economic situation, which makes the idea of the property-owning democracy increasingly untenable.

Though May's change of tack on housing managed to garner approval from numerous housing organizations and media outlets (such as Shelter or Inside Housing), it is generally held that the implementation of her plans was significantly hampered by the Brexit process as well as the short duration of her office (Apps, 2019). Therefore, it may be further necessary to examine the discourse of her successor Boris Johnson and compare it with his actual housing record to see whether May's housing U-turn was a real start of a new course or a temporary detour in the incessant Conservative chase for the property-owning democracy myth. 


\section{[Notes]}

1 After adjusting for inflation, average house prices in England have increased by $173 \%$ since 1997 , while adults' real incomes have increased by only $19 \%$. Consequently, the share of 25 - to 34 -year-olds owning their own home fell from $55 \%$ to $35 \%$ between 1997 and 2017. For more information see https://ifs.org.uk/publications/13471.

2 For more information on the principles and practice of the DHA, see Reisigl and Wodak, 2009.

3 The poorest slum dwellers were expected to move to the homes vacated by the more aspirational workers who became tenants in the new-built estates, a process known as "filtering up".

4 For more information on the implementation of this measure in favour of renters, see: https://www.gov.uk/government/news/government-announces-end-to-unfair-evictions. Accessed August 15, 2021.

5 The Conservative use of the word "fairness", however, often tends to carry strong moral overtones, referring in fact to the elimination of welfare abuse by the undeserving poor. This is not the case of May's use of the concept.

6 Martin Rogers, All parties stand for 'fairness', but what voters perceive to be 'fair' is up for grabs.

7 In 2019, $46 \%$ of private renters and $45 \%$ of social renters voted for Labour (against only $31 \%$ and $33 \%$ for the Conservatives); see https://www.newstatesman.com/politics/uk-politics/2021/05/how-tory-dominance-built-home-ownership.

\section{[Bibliography]}

Apps, P. (2019, May 24). Theresa May's Legacy on Housing: Bold Ambitions Unfulfilled. Ball, S. (1998). The Conservative Party since 1945. Manchester, Manchester University Press.

Boughton, J. (2018). Municipal Dreams: The Rise and Fall of Council Housing. London, Verso. Fairclough, N. (1992). Discourse and Social Change. Cambridge: Polity Press.

Flint, M. (2021, November 21). Changing the Face of the British Rental Market. Essential Living. Retrieved from https://www.essentialliving.co.uk/blog/changing-the-face-ofthe-british-rental-market/.

Gimson, A. (2013, October 17). How Macmillan Built 300,000 Houses a Year. Conservative Home. Retrieved from https://www.conservativehome.com/thetorydiary/2013/10/ how-macmillan-built-300000-houses-a-year.html.

Greenbaum, S. (1996). The Oxford English Grammar. Oxford: Oxford University Press. Hanley, L. (2012). Estates. An Intimate History. London, Granta Publications. Hunt, T. (2004, February 2). How the English Became Obsessed with Property. New Statesman. Retrieved from https://www.newstatesman.com/node/194947.

Kentish, B. (2017, October 4). Theresa May's Speech: All the Policies She Stole from Jeremy Corbyn. The Independent. Retrieved from https://www.independent.co.uk/ 
news/uk/politics/theresa-may-jeremy-corbyn-policies-labour-stole-list-conference-speech-organ-donor-tuition-fees-housing-a7983191.html?r=90227.

Inside housing (2019, June 26). Theresa May's Speech at Housing 2019 [video]. Youtube. Retrieved from https://www.youtube.com/watch?v=iqKgDb2Ofg4.

Jameson, H. (2014, October 27). Labour to Raise HRA Cap - for Some. The MJ. Retrieved from https://www.themj.co.uk/Labour-to-raise-HRA-cap---for-some/198593.

Meyer, M. (2001). Between Theory, Method, and Politics: Positioning of the Approaches to CDA. In R. Wodak and M. Meyer (Eds). Methods of Critical Discourse Analysis (14-32). Sage: London.

PM's Speech on Housing: 26 June 2019 (2019, June 26). Gov.UK. Retrieved from https:// www.gov.uk/government/speeches/pms-speech-on-housing-26-june-2019.

Reisigl, M. (2018). The Discourse-Historical Approach. In: E. Flowerdew and J. Richardson (Eds.). The Routledge Handbook of Critical Analysis (44-59). Routledge, New York.

Reisigl, M., Wodak, R (2017) The Discourse Historical Approach. In R. Wodak and M. Meyer (Eds). Methods of Critical Discourse Analysis (87-121). Sage: London.

Sandbrook, D. (2019). Who Dares Wins. Britain 1979-1982. London, Allen Lane.

Rogers, M. (2014). All Parties Stand for 'Fairness', but What Voters Perceive to Be 'Fair' Is Up for Grabs, LSE. Retrieved from http://eprints.lse.ac.uk/48432/1/blogs.lse.ac.ukAll_parties_stand_for_fairness_but_what_voters_perceive_to_be_fair_is_up_for_ grabs.pdf

Ron, A. (2008). Visions of Democracy in Property-Owning Democracy: Skelton and Rawls and Beyond. In History of Political Thought, Vol. 29, No. 1. Retrieved from https://www.jstor.org/stable/26224022?seq=1.

Tihelková, A. (2015). Framing the 'Scroungers': the Re-emergence of the Stereotype of the Undeserving Poor and Its Reflection in the British Press. Brno Studies in English, 41(2), 2,122-139. Brno: Masaryk University. Retrieved from: https://digilib.phil.muni. cz/bitstream/handle/11222.digilib/135030/1_BrnoStudiesEnglish_41-2015-2_10.pdf?sequence=1.

Tihelková, A. (2018). Shaped by the Housing Crisis: Britain's Generation Rent. From Theory to Practice 2016: Proceedings of the Eighth International Conference on Anglophone Studies. Zlín, Univerzita Tomáše Bati ve Zlíně, 193-202. Retrieved from http://conference.uaa.utb.cz/tp2016/FromTheoryToPractice2016.pdf.

van Dijk, T. (2003). Critical Discourse Analysis. In D. Schiffrin, D. Tannen and H.E. Hamilton (Eds.). The Handbook of Discourse Analysis (352-372). London: Blackwell. Watt, N. (2012, April 3). David Cameron Launches New Right-to-Buy Scheme for Social Housing. The Guardian. Retrieved from https://www.theguardian.com/society/2012/ apr/03/cameron-right-to-buy-housing.

Wodak, R. (2018) We Have the Character of an Island Nation. A Discourse-Historical Analysis of David Cameron's "Bloomberg Speech" on the European Union. In Kranert, E. and Horan, G. (Eds.). Doing Politics: Discursivity, Performativity and Mediation in Political Discourse (27-58). Amsterdam: John Benjamins. 


\section{[Address]}

Department of English Language and Literature

Faculty of Arts

University of West Bohemia

Sedláčkova 15

Plzeň

Czech Republic

atihelko@kaj.zcu.cz

quinnov@kaj.zcu.cz

Alice Tihelková studied History as well as English and American Studies at Charles University in Prague, where she also obtained her PhD in English Language in 2006. In 2002 she joined the Department of the English Language and Literature, Faculty of Philosophy and Arts, University of West Bohemia in Plzeñ, where she still teaches, mainly courses in British Cultural Studies and English for Special Purposes. She uses her background to study contemporary British society and culture from an interdisciplinary perspective. He main focus of interest is political and media discourse on Britain's class system and the class stereotypes used by the commentariat, politicians and other actors. She also takes an avid interest in the history of public housing in the UK.

Veronika Quinn Novotná studied English and American Studies and German Studies at the Faculty of Arts of Charles University in Prague, where she also completed her PhD in English. Since 2019, she has been teaching linguistics courses at the Department of English Language and Literature at the Faculty of Arts, University of West Bohemia in Plzeň. She also teaches academic writing, presentation skills and creative writing in English. In her research activities, she specializes in Global/World Englishes/English as a Lingua Franca. 